\title{
Effects of Near-Fault Earthquakes on the Seismic Performance of Steel-Frame Buildings with Vertical Mass Irregularities
}

\author{
Hossein Abdollahiparsaa ${ }^{1 *}$, Shahram Rizaneh ${ }^{2}$, Saeid Abdollahiparsa ${ }^{3}$ and Mohammad hassan \\ mohagheghdolatabadi ${ }^{3}$
}

${ }^{1}$ Department of the Built Environment, Eindhoven University of Technology, Eindhoven, Netherlands

${ }^{2}$ Department of Mechanical and Manufacturing Engineering, University of Calgary, Canada

${ }^{3}$ Department of Civil Engineering, Qom Branch, Islamic Azad University, Qom, Iran

Submission: January 30, 2021; Published: March 03, 2021

*Corresponding author: Hossein Abdollahiparsaa, Department of the Built Environment, Eindhoven University of Technology, Eindhoven, Netherlands

\begin{abstract}
This study explores the effects of vertical mass irregularities on the seismic response of multistoried moment-resisting steel structures by considering mass discontinuity at the top and first stories. Perform 3D software is used to carry out an inelastic dynamic analysis of time histories of 3-, 5-, and 8-storey steel frame buildings subjected to 10 near-field earthquake events. Comparison of the analytical results reveals that the axial forces on both the interior and exterior columns in all cases are at their maxima $(30 \%-40 \%)$ in the top storey and at their minima in the 1st storey, respectively. Structures with mass irregularities in their top stories are observed to experience slightly larger horizontal roof displacements than those with irregularities in their 1st storey. Larger vertical displacements at beam mid-points are observed in structures with mass irregularities in their top stories than in those with irregularities in their 1st storey while the base shear forces are found to decrease by about $6 \%$. Compared to structures with mass irregularities in their lower stories, those with vertical irregularities in their top stories exhibit a poorer performance under near-field earthquakes.
\end{abstract}

Keywords: Vertical mass irregularity; Seismic analysis; Near-field earthquake

\section{Introduction}

Buildings of any level of perfection might exhibit irregularities in their design or construction. Moreover, buildings subjected to seismic activities might fail due to irregularities caused by changes in, or upgrade of, their design layout. Earthquake damages to structures with irregularities in their structural properties are indications of their insufficient strength [1,2]. Many research efforts have been devoted over the years to the behavior of buildings with a non-uniform mass distribution and the absence of inadequate provisions or relevant construction code requirements. Buildings with mass irregularities along their heights are defined in most codes as those with mass discontinuity. According to the Uniform Building Code [3], irregular structures are those in which one storey is by $150 \%$ greater in mass than its adjacent one. The EC8 seismic code [4] requires the use of the response spectrum method to identify irregular buildings and that a $20 \%$ reduction should be considered in their q factor.
Al-Ali et al. found that variation in mass along the height of a building had only slight effects on its inelastic response parameters [5]. Using both static and multimodal analyses to design four five-storey shear-type frames, Magliulo et al. observed no clear differences regarding the type of analysis between irregular and regular structures [6]. Choi showed plastic hinge rotation and hysteretic energy distribution to occur most seriously in the upper or lower stories of buildings with mass irregularities. The author concluded that mass irregularity could be a major factor involved in response to seismic loading [7]. Investigating vertical irregularities in lateral strength, mass, and stiffness, Chintanapakdee and Chopra identified lateral strength irregularity as the one with the greatest impact [8]. In their assessment of different seismic codes, Satrajit and Nau investigated the effects of the requirements and constraints in the codes on using simplified methods for designing structures characterized by 


\section{Civil Engineering Research Journal}

consistent vertical irregularities in different types of multi-storey reinforced concrete $(\mathrm{RC})$ buildings with vertical irregularities at different points [9]. Lower base shear forces but higher interstorey drifts were reported by Himanshu and Gagandeep in stiff irregular structures; these authors carried out both time histories and response spectrum analyses on vertically irregular RC building frames with maximized shear force in their $1^{\text {st }}$ storey but minimized in the top one [10]. Lignos and Gantes employed modal pushover and time history analyses in their evaluation of irregular frames to find significantly different storey drifts in elastic structures. The authors also reported frequently underestimated demands for height-wise distribution of deformation in the upper stories [11]. Some authors maintained that this demand was highly affected not only by the position of the heavier mass and the degree of inelastic deformation but also by the fact that elastic height-wise distributions of deformation demand tended to be uniform but that inelastic ones were concentrated in the lower stories [12,13]. This is while application of dynamic analysis for vertically irregular structures as recommended by major seismic codes has been called into question by Tremblay and Poncet [12]

Using numerical analysis, building response has been shown by Poonam et al. to rise as a result of irregularity in mass distribution. These authors observed that appropriate provisions need to be introduced into the procedures for the design and analysis of buildings to handle these irregularities in a proper manner [14]. Alirezaei and Vahdani investigated seismic demand in tall buildings with irregularities due to setback. The authors determined global drift, storey drift, and storey displacement in such buildings and observed enhancements in both global drift of the structure and deformation along its height with increasing vertical irregularity [15]. Vela and Javier studied a structure with a concentrically-braced frame supporting a cylindrical storage steel tank. They developed a dynamic interaction model within a computational framework to simulate the storage system behavior [16]. The two code-compliant approaches proved rather weak in predicting tank behavior due to the extremely underestimated acceleration demand for a wide range of periods, especially those close to the basic course of the structure. In another study, both these methods were used to evaluate the performance of the supporting frame in its interaction with the liquid storage tank. Moreover, the results thus obtained were compared with those obtained from indirect analysis that had, in turn, been predicted based on direct analysis [17]. In their study of ten seismic responses of asymmetric in-plane structures to far-fault and nearfault ground motions, Shakib and Ghasemi found that buildings subjected to near-fault motions exhibited actual rotational responses, which obviously did not agree with the assumptions commonly made about the seismic behavior of such structures [18]. In many cases, the effects of VGM on building structures (including non-structural components) and infrastructural facilities are of such a great importance that they could at times be included among the most critical issues to be duly considered in the structural design and analysis. For example, strong VGMs might induce significant increases in the axial forces in columns or in the vertical displacement of beams [19].

The previously reported results on the seismologic characteristics of near-field earthquakes and the inadequacies observed in the relevant codes, especially in the absence of evidence on the likely effects of significant mass discontinuities on the seismic responses of buildings, call for revisiting the seismic design procedures commonly recommended for structures in earthquake-prone areas to formulate more accurate design codes based on realistic criteria. Thus, the current study was conducted to determine what impacts, if any, the location of mass irregularities along the height of steel-frame buildings designed based on the Iranian Seismic Code would have on their responses to such motions [20]. It was hypothesized that nearfield earthquake excitations should have a major impact on the seismic performance of structures designed based on the static analysis method.

\section{Methodology}

For the purposes of this study, real buildings were designed to fulfill different functions at several levels over their height, such as floors used for heavy mechanical installations, car parking floors, or those utilized for commercial purposes. Current design codes contain the criteria for the classification of "irregular" structures. The most influential types of vertical irregularity are those of mass, stiffness, geometry, and lateral strength. For structures with vertical irregularities in stiffness, mass, or geometry, current guidelines require the use of dynamic analysis (seismic response history procedure or modal response spectrum analysis) to determine the associated lateral force distribution [21]. Each code prescribes its own specific limits for these irregularities. One such limit identifies mass irregularity in buildings as one in which the seismic weight of each storey exceeds that of the adjacent storey by $150 \%$. It should be noted that structural design and evaluation become more complicated when buildings are constructed in highly earthquake-prone zones due to the forward-directivity effects in the near-fault regions. A major interest of researchers is the study of various engineering and seismologic topics that deal with pulse-like ground motions caused by directivity effects; these include ground motion prediction ("attenuation") models, nonlinear dynamic analysis, and probabilistic seismic hazard analysis of structures [22]. Accordingly, the modeling of the reference structures used in this study was meant to allow for comparisons of mass irregularities in steel structures at two heights on different stories (i.e., the top and the first) during nearfault ground motions.

\section{Specifications of the study buildings}

For our purposes, inelastic dynamic THA of all the frames was performed in Perform-3D [23] to explore material inelasticity and geometric nonlinearity of large inelastic deformation in individual 
members and structures exposed to seismic loading. The study was performed on 3-, 5-, and 8-storey steel moment-resisting frames (MRF) with a storey height of $3.2 \mathrm{~m}$ and a bay length of $5 \mathrm{~m}$ for all the floors; this is schematically shown in Figure 1. In order to examine the effect of weight (mass) discontinuity during near-fault earthquakes, three building configurations were established and designed according to the provisions made in the
Iranian Seismic Code [20] on high ductility class buildings. The study was carried out on steel structures and mass irregularities were considered on the first and top floors used for commercial purposes, car parking floors, or heavy mechanical installations. Obviously, the different uses of two adjacent floors results in mass irregularity. Figure 2 is a detailed schematic side view of structures with 5-story frames based on 2D analysis.
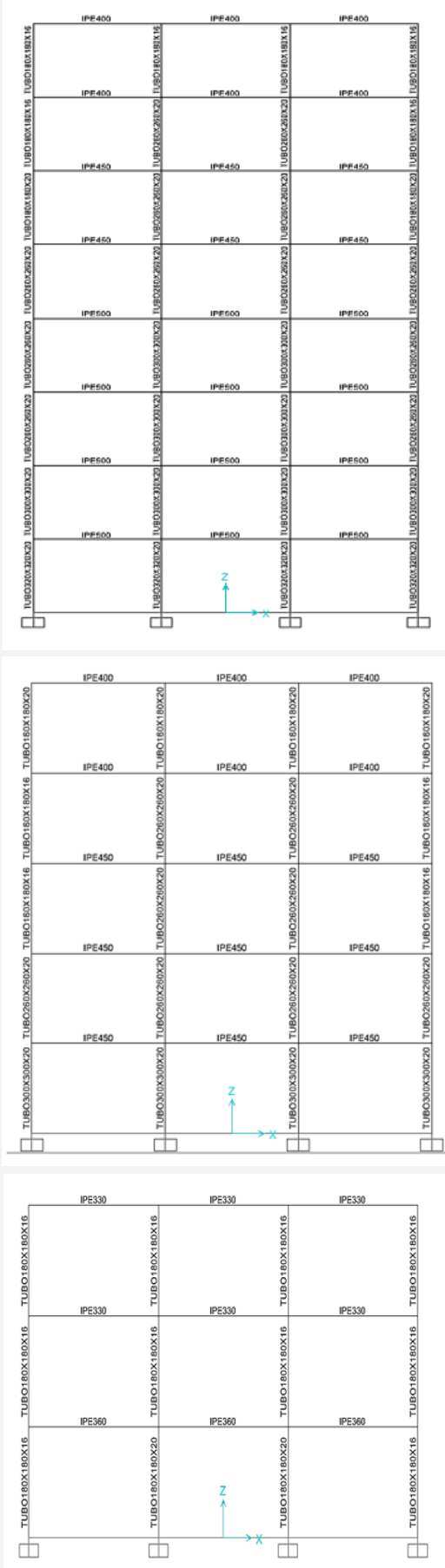

Figure 1: Schematic view of 3-, 5-, and 8-storey MRFs. 

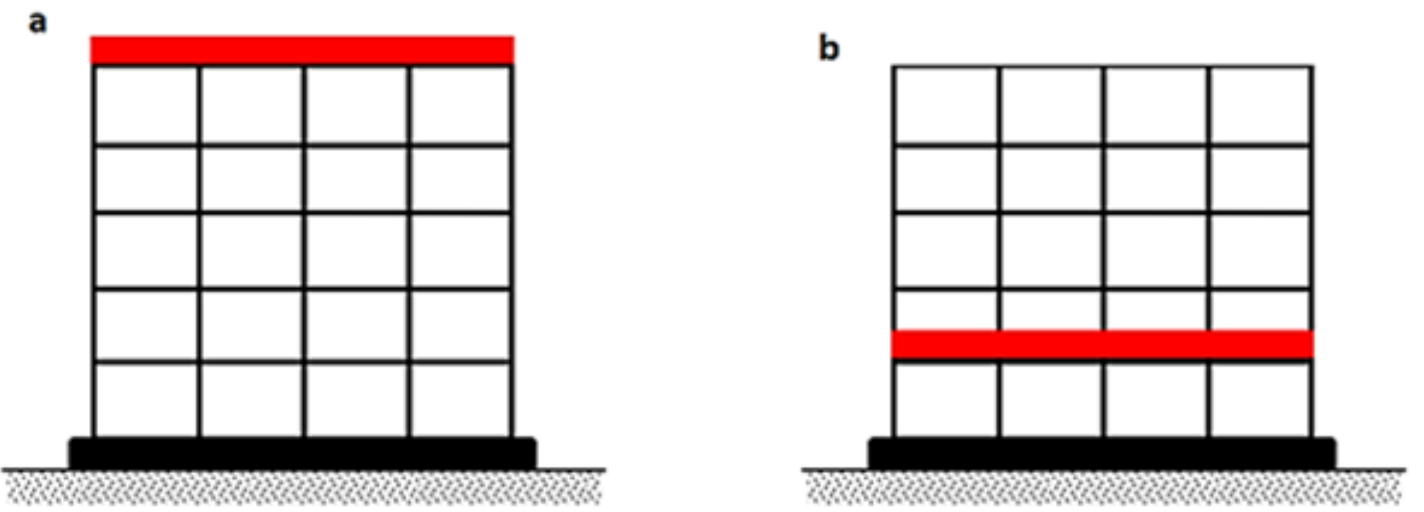

Figure 2: Mass irregularity along the height of 5-story frames: a) top floor, and b) first floor.

Iranian loading standards allow for live loads equal to $200 \mathrm{~kg} /$ $\mathrm{m}^{2}$ and dead loads equal to $600 \mathrm{~kg} / \mathrm{m}^{2}$. Moreover, all the members are assumed to consist of rigid and connected beams and columns framing the construction designed to resist not only gravity loads but also maximum forces expected during an inelastic response. In this experiment, the beams of the selected frames were designed according to the European IPE sections while the Box sections were used for the columns. The elements exhibited a bilinear hysteretic response for a strain hardening of $2 \%$. The nonlinear time history dynamic analysis was also performed in Perform3D computer software with the P-delta effects considered in the calculations and a modal damping ratio of $2 \%$ considered for the 1st and 3rd modes in all the analyses to obtain the values for $\mathrm{a}_{0}$ and $a_{1}$ in Rayleigh damping [24]. Ten near-field ground motions were applied in the THA analysis of each building frame in order to improve the building response as a result of using dynamic analysis in the design process. Finally, these provisions led to a difference of greater than $150 \%$ in weight between the upper and lower stories as required by the Iranian codes. This was meant to allow for the evaluation of structural sensitivity to mass irregularity type and to ensure that higher levels of irregularity would be allowed for the types of structure studied.

\section{Earthquakes}

Ground-shaking motions taking place at different distances are considered to be near-field earthquakes. However, no specific distance has been mentioned for identifying a specific site as a far- or a near-field earthquake. Some researchers have used the dimension of the source relative to that of the source-tosite distance as a useful measure for defining a zone as a nearfield earthquake. The effects of near-fault ground motions were compared in terms of rotation and displacement demands. For this purpose, a suite of earthquakes comprising ten near-source records of the historical ground motion time histories were obtained from the Pacific Earthquake Engineering Research Center (PEER) to which the study structures were subjected [25]. Table 1 reports a list of the ground motions and the accelerograms along with their characteristics.

Table 1: Data for all the fault-normal ground motions used.

\begin{tabular}{|c|c|c|c|}
\hline Earthquake & Station & Vertical PGA ${ }_{v}(g)$ & Horizontal PGA $_{H}(\mathrm{~g})$ \\
\hline \multirow{4}{*}{ Northridge, CA 17-01-1994 } & Arleta $(9.2 \mathrm{~km})^{*}$ & 0.552 & 0.344 \\
\hline & Newhall $(7.1 \mathrm{~km})$ & 0.548 & 0.59 \\
\hline & Sylmar (6.4 km) & 0.535 & 0.843 \\
\hline & Tarzana $(17.5 \mathrm{~km})$ & 1.048 & 1.779 \\
\hline Loma Prieta, CA 18-10-1989 & Capitola (14.5 km) & 0.541 & 0.529 \\
\hline Morgan Hill, CA 24-04-1984 & Gilroy Array (14.6 km) & 0.395 & 0.2 \\
\hline Westmorland, CA 26-04-1981 & Westmorland Fire (13.3 km) & 0.838 & 0.496 \\
\hline Erzincan, Turkey 13-03-1992 & Erzincan $(7.7 \mathrm{~km})$ & 0.234 & 0.496 \\
\hline Imperial Valley, CA 06 15-10-1979 & Brawley Airport (10.4 km) & 0.153 & 0.219 \\
\hline Kobe, Japan 16-01-1995 & Nishi-Akashi (11.1 km) & 0.371 & 0.509 \\
\hline
\end{tabular}




\section{Civil Engineering Research Journal}

\section{Results and Discussion}

Scholars surveying the Iranian Seismic Design Code urge that it needs to be revisited and duly modified as have those elsewhere (e.g., Canada and US) $[3,26]$. These studies base their claims not only on reports of devastating earthquakes in the past but also on the fact that the insidious impacts of strong near-field ground motions containing directivity and fling step cannot be ignored $[2,22]$. In this regard, the seismologic characteristics of near-field earthquakes, the incongruities in code requirements, and the scant evidence presently available on the effects of significant mass discontinuities on the seismic response of buildings warrant a more careful and closer examination of the seismic design codes for structures in earth-quake prone areas. The current study was undertaken to determine whether or not the position of mass irregularities on the upper or lower floors of steel-framed buildings would have a major effect on the seismic performance of structures. For this purpose, 3-, 5-, and 8-storey steel MRFs prone to near-field ground motions were evaluated with respect to their seismic performance and compared with the design criteria in the Iranian seismic code. The evaluation was based on measurements of column axial force, vertical displacement at mid-beam height in each storey, roof horizontal displacement, and base shear forces for each ground motion. The objective of the study was twofold: 1) to achieve a more conclusive assessment of the effects of mass irregularity at different building heights (Upper and Lower floors), and 2) to gain a better understanding of the advantages of dynamic analysis. The mean response values for the buildings designed according to THA are depicted in (Figures 3-6).
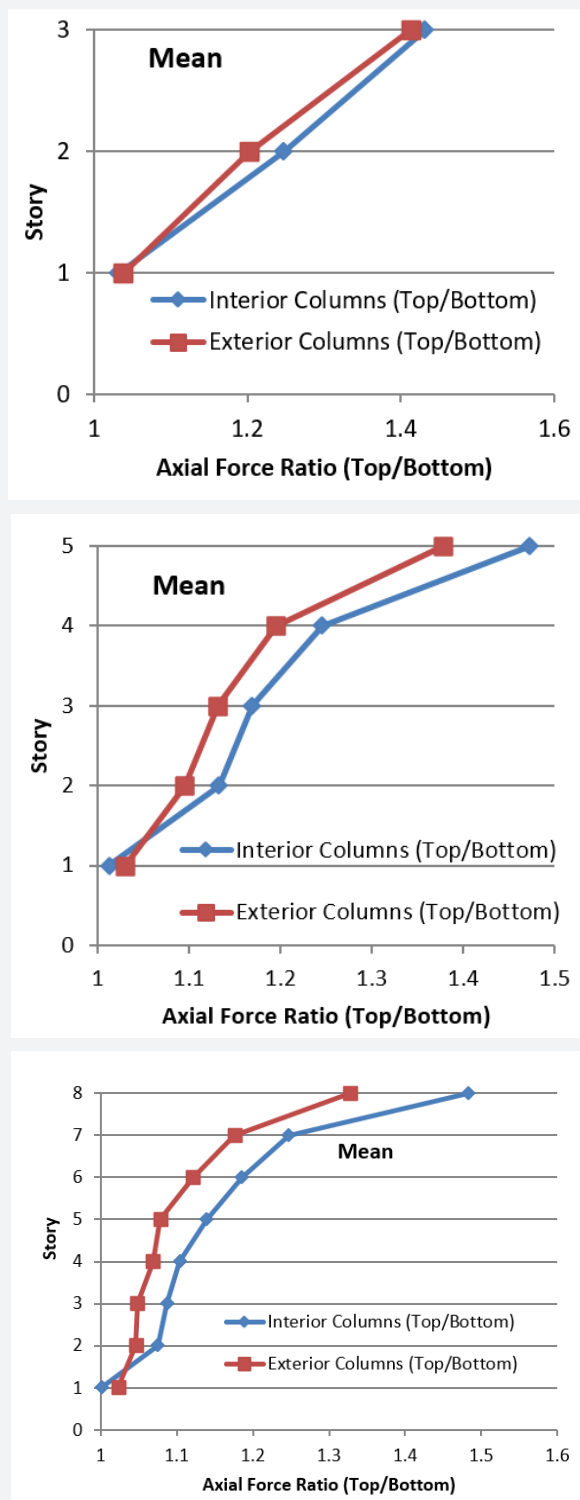

Figure 3: Axial force ratios of the exterior and interior columns in the 3-, 5-, and 8-storey frames considered. 

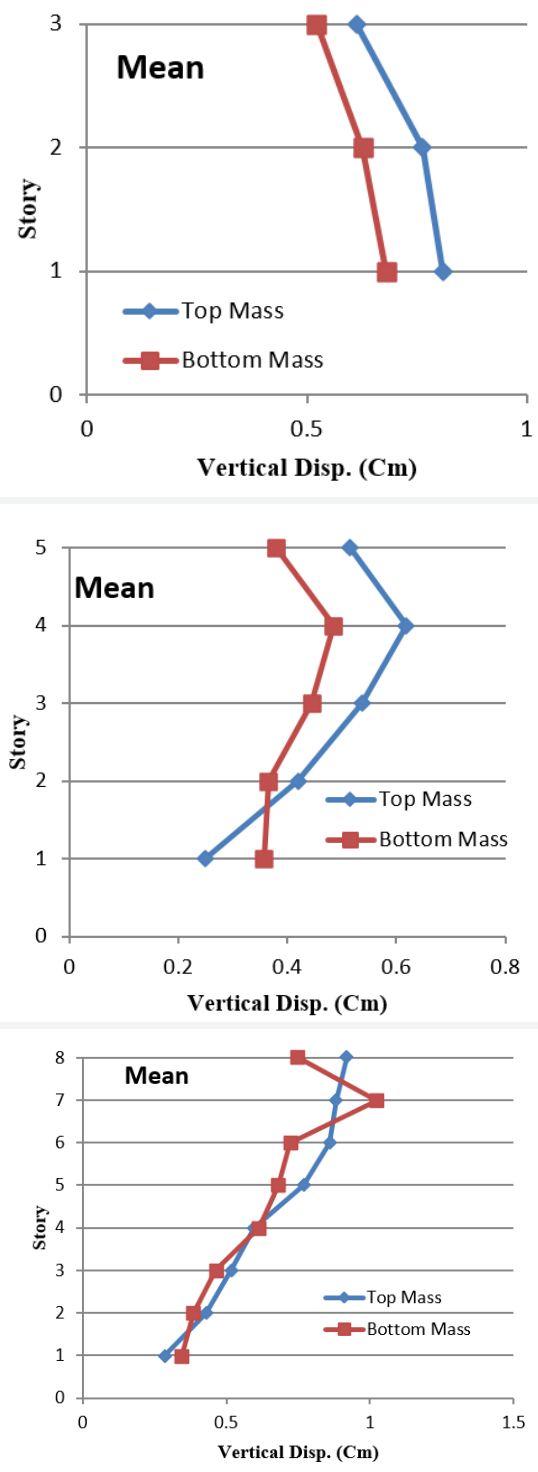

Figure 4: Vertical displacement at beam mid-point in 3-, 5-, and 8-storey frames.

\section{Column axial force}

The axial force of the column was strongly affected by mass irregularity and near-field earthquake, especially in columns with greater gravity loads. Evaluation of the axial forces of the exterior and interior columns indicated that these factors affected the interior columns more than they did the exterior ones. Based on mean building responses to the ten earthquakes examined, mass irregularity in the top storey, compared to that in the first storey (top/bottom), was found to have a greater effect on the axial forces of exterior columns than on those of interior ones $10 \%$ to $40 \%$ ). As the number of stories increased, the axial force ratio of the columns was observed to increase in all cases, indicating the significance of column location and conditions in the structure.

\section{Vertical displacement at beam mid-points}

Vertical displacement at beam mid-points in frames with a lower number of floors was found strongly influenced by both the location of mass irregularity along the height of the steelframe building and the near-field earthquake excitations. THA responses for vertical displacement decreased in value (by about $20 \%$ ) at beam mid-point in frames with mass irregularities in their lower floors (namely, the first storey) relative to those recorded for structures in which mass irregularity occurred in their upper floors. Hence, the serious impacts of beam vertical displacement should be duly considered in the design of important structures such as hospitals since they have been shown to have repercussions for the performance of nonstructural elements. 


\section{Civil Engineering Research Journal}

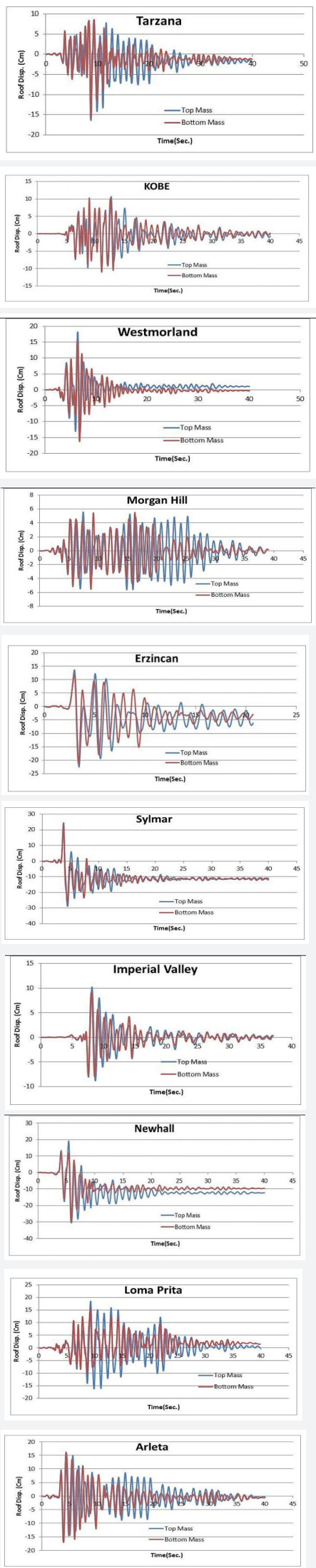

Figure 5: Roof horizontal displacement in a 5-storey frame with mass irregularities for different earthquake events. 


\section{Civil Engineering Research Journal}

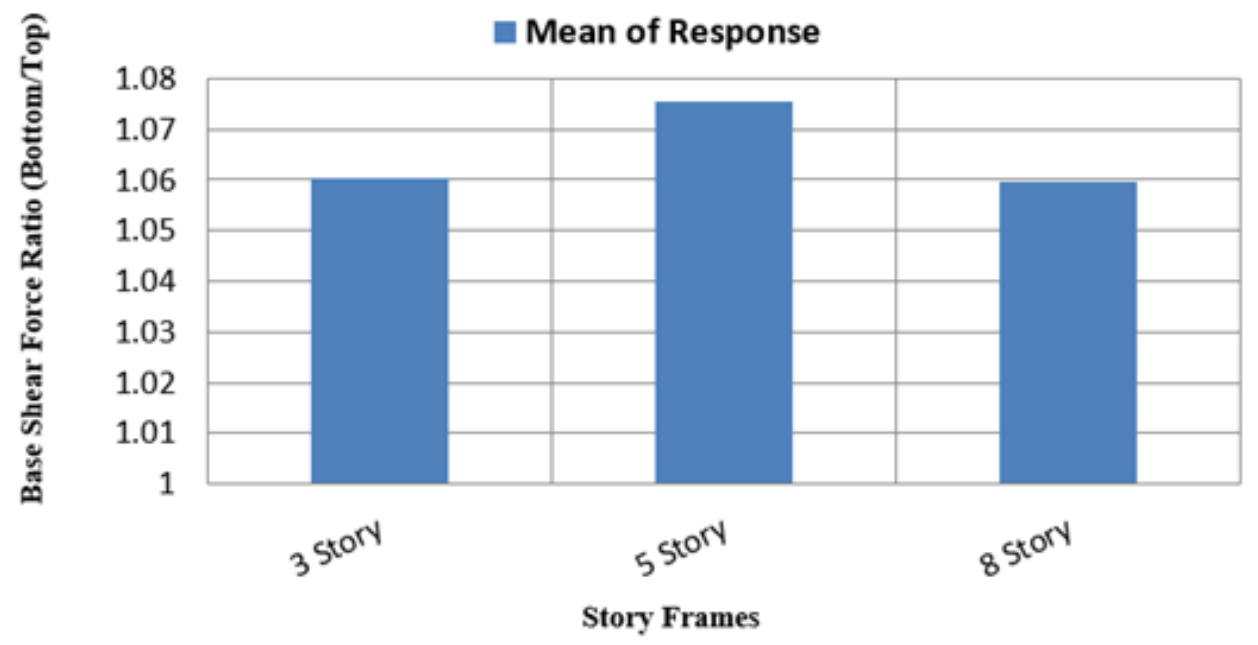

Figure 6: Base shear ratio (bottom/top) of columns in the 3-, 5-, and 8-storey frames for different earthquakes.

\section{Horizontal displacement of roof story}

Near-fault earthquakes are characterized by high frequency motions in the vertical direction and long-duration pulses in the horizontal direction, both exerting significant amounts of input energy on structures at the beginning of the event. In cases where mass irregularity occurs in the upper floors of a structure, the responses to THA show slightly higher horizontal displacements in the upper stories than they do when the mass irregularities occur at the lower floors. Figure 5 shows the time histories of horizontal displacement at the roof level in a 5-storey frame subjected to all the earthquakes considered. Similar results (Data not shown to save space) were obtained for the 3- and 8-storey frames subjected to the same ground motions.

\section{Base shear force}

No significant changes were observed in the base shear ratios (bottom/top) of columns in 3-, 5-, and 8 storey frames with mass irregularities in their bottom and top stories. Examination of only one of the cases was found sufficient for the analysis of base shear ratio. Figure 6 shows the differences in base shear ratio between the lower and upper stories for each (3-, 5-, and 8 storey) model. Clearly, all the cases examined exhibited equal increases of about $5 \%$, which is negligible for a seismic response of any impact. Moreover, it is seen that base shear ratio tended to increase for mass discontinuities located in the lower stories.

\section{Conclusion}

Nonlinear dynamic analyses of 3-, 5-, and 8-storey steel MRFs with mass irregularities were conducted to investigate the performance of reference structures exposed to a suite of ten earthquake ground motions. The following conclusions were drawn about the structural behavior of the buildings based on the analysis of their near-field earthquake time histories. Both the axial forces of the columns (especially the interior ones) and vertical displacement at beam mid-point were observed to increase by nearly $40 \%$ and $20 \%$, respectively, when mass discontinuity occurred in the top storey rather than in the 1st. This indicated the more destructive effect of top storey mass discontinuity on the seismic performance of structures. Neither roof horizontal displacement nor column base shear underwent any significant changes under strong near-field excitations when the mass discontinuity was located in the top storey rather than in the 1st. It may, therefore, be recommended that the analytical results obtained for one story suffice for the analysis of structures with mass irregularity. Moreover, placement of mass irregularity in lower stories is recommended for the design and construction of MRF systems subjected to near-field earthquakes in order to prevent structural failure due to such weaknesses as caused by mass discontinuity. Despite the useful insights into the seismic response of frames with vertical mass discontinuities gained by the present study and those reported in the literature, further investigation of buildings with different mass conditions are required to verify the results reported here and to formulate final practicable design recommendations.

Conflict of Interest: The authors declare that they have no conflict of interest.

\section{References}

1. Penelis GG, Kappos AJ (1997) E Earthquake-resistant Concrete Structures. FN SPON. Earthquake-Resistant Concrete Structures E\&FN Spon.

2. Spyropoulos Pan J (1982) Report on the Greek earthquakes of February 24-25, 1981. Concrete International 4(2): 11-15. 


\section{Civil Engineering Research Journal}

3. (1997) International Conference of Building Officials. Uniform building code. International Conference of Building Officials.

4. (1993) ENV, CEN. 1-1. Eurocode 3: Design of steel structures-part 1-1: General rules and rules for buildings. European Commitee for Standardization.

5. Al-Ali, Ali AK, Helmut Krawinkler (1999) Effects of vertical irregularities on seismic behavior of building structures. John A. Blume Earthquake Engineering Center.

6. Magliulo G, Ramasco R, Realfonzo R (2002) Seismic behaviour of irregular in elevation plane frames. Proceedings of the $12^{\text {th }}$ European conference on earthquake engineering.

7. Choi, Byong Jeong (2004) Hysteretic energy response of steel moment resisting frames with vertical mass irregularities. The Structural Design of Tall and Special Buildings 13(2): 123-144.

8. Chintanapakdee, Chatpan, Anil Chopra K (2004) Seismic response of vertically irregular frames: response history and modal pushover analyses. Journal of Structural Engineering 130(8): 1177-1185.

9. Das, Satrajit, James Nau M (2003) Seismic design aspects of vertically irregular reinforced concrete buildings. Earthquake Spectra 19(3): 455-477.

10. Lignos DG, Gantes CJ (2005) Modal pushover analysis as a tool for evaluation and design of irregular frames. Third MIT Conference on Computational Fluid and Solid Mechanics pp: 336-339.

11. Karavasilis, Theodore L, Nikitas Bazeos, Beskos DE (2008) Estimation of seismic inelastic deformation demands in plane steel MRF with vertical mass irregularities. Engineering structures 30(11): 32653275 .

12. Tremblay R, Poncet L (2005) Seismic performance of concentrically braced steel frames in multistorey buildings with mass irregularity. Journal of Structural Engineering. 131(9): 1363-75.

13. Himanshu Bansal, Gagandeep (2012) Seismic Analysis and Design of Vertically Irregular RC Building Frames. International Journal of Science and Research (IJSR), ISSN (Online) 3(8): 2319-7064.

14. Poonam, Anil Kumar, Asoka Gupta K (2012) Study of response of structurally irregular building frames to seismic excitations. International Journal of Civil, Structural, Environmental and Infrastructure Engineering Research and Development 2(2): 25-31.
15. Alirezaei A, Vahdani S (2015) Estimation of Seismic Deformation Demands of Tall Buildings with Symmetric Setbacks. World Academy of Science, Engineering and Technology, International Journal of Civil, Environmental, Structural, Construction and Architectural Engineering 9(4): 393-396.

16. Merino Vela, Roberto Javier, Emanuele Brunesi, Roberto Nascimbene (2018) Floor spectra estimates for an industrial special CBF structure.

17. Vela RJ, Merino E, Brunesi, Nascimbene R (2018) Derivation of floor acceleration spectra for an industrial liquid tank supporting structure with braced frame systems. Engineering Structures 171: 105-122.

18. Shakib, Hamzeh, Abbas Ghasemi (2007) Considering different criteria for minimizing torsional response of asymmetric structures under near-fault and far-fault excitations. International Journal of Civil Engineering 5(4): 247-265.

19. Abdollahiparsa, Hossein, Peyman Homami, Faramarz Khoshnoudian (2016) Effect of vertical component of an earthquake on steel frames considering soil-structure interaction. KSCE Journal of Civil Engineering 20(7): 2790-2801.

20. (2005) Code, Iranian Seismic. Iranian code of practice for seismic resistant design of buildings. Standard.

21. (2016) Engineers A. S. O. C. Minimum design loads for buildings and other structures. ASCE 710.

22. Baker Jack W (2007) Quantitative classification of near-fault ground motions using wavelet analysis. Bulletin of the Seismological Society of America 97(5): 1486-1501.

23. (2011) CSI (Computers and Structures Inc.). Structural and Earthquake Engineering Software, PERFORM-3D, Nonlinear Analysis and Performance Assessment for 3-D Structures, V5.0.0, Berkeley, CA, USA.

24. Chopra, Anil K, Frank Mc Kenna (2016) Modeling viscous damping in nonlinear response history analysis of buildings for earthquake excitation. Earthquake Engineering \& Structural Dynamics 45(2): 193211.

25. Pacific earthquake engineering research centre (PEER), Strong ground motion database, http://peer.berkeley.edu.

26. Abdollahiparsa H, Homami P, Dehnamaki V (2015) Influence of Site and Soil Characteristics on Uniform Hazard Spectra of Andimeshk Site. Asian Journal of Civil Engineering (BHRC) 16(7): 1037-1045

\section{Your next submission with Juniper Publishers will reach you the below assets}

- Quality Editorial service

- Swift Peer Review

- Reprints availability

- E-prints Service

- Manuscript Podcast for convenient understanding

- Global attainment for your research

- Manuscript accessibility in different formats

( Pdf, E-pub, Full Text, Audio)

- Unceasing customer service

Track the below URL for one-step submission https://juniperpublishers.com/online-submission.php 